\title{
PEMBENTUKAN KARAKTER PESERTA DIDIK MELALUI PROGRAM SEKOLAH SEHAT DAN RAMAH ANAK DI SMP NEGERI 7 KOTA TERNATE
}

\author{
Sitirahia Hi Umar ${ }^{1}$, Mirnawati Umawaitina ${ }^{2}$ \\ ${ }^{1}$ Dosen Program studi Pendidikan Pancasila dan Kewarganegaraan FKIP Unkhair \\ ${ }^{2}$ Mahasiswa Program studi Pendidikan Pancasila dan Kewarganegaraan FKIP Unkhair
}

Author Correspondence: sitirahia@ yahoo.com

$\begin{array}{ll}\text { Diterima } & : 20-02-2019 \\ \text { Direvisi } & : 30-03-2019 \\ \text { Dipublikasi } & : 01-05-2019\end{array}$

\begin{abstract}
Abstrak. Penelitian ini dilator belakangi oleh hubungan sosial antara peserta didik dengan masyarakat lingkungan sekolah dilihat dari pola pembentukan karakter peserta didik melalui sekolah sehat dan ramah anak. Penelitian ini bertujuan untuk mengkaji lebih dalam tentang faktor-faktor yang mempengaruhi pembentukan karakter melalui sekolah sehat dan ramah anak, sikap kedisiplinan peserta didik, serta keramahan di lingkungan sekolah SMP Negeri 7 Kota Ternate dengan titik tekan kajian yaitu untuk mengetahui pembentukan karakter peserta didik melalui program sekolah sehat dan ramah anak. Metode yang digunakan dalam penelitian ini adalah tipe kualitatif deskriktif. Penelitian kualitatif sebagai prosedur penelitian yang menghasilkan data deskriktif berupa kata-kata tertulis atau lisan dari orang-orang yang berperilaku yang dapat diamati. Kepala sekolah, guru dan peserta didik. Subyek penelitian menggunakan teknik 'Purposive Sampling'. Sumber data yang digunakan dalam penelitian ini adalah data primer dan data sekunder. Teknik pengumpulan data adalah observasi, wawancara dan studi dokumentasi. Hasil penelitian menunjukkan bahwa pola pembentukan karakter peserta didik melalui sekolah sehat dan ramah anak di SMP Negeri 7 Kota Ternate telah terlaksana dengan baik. Hal ini dibuktikan dengan sikap kedisiplinan dan selalu bersikap ramah di lingkungan sekolah. Faktor-faktor yang mempengaruhi pembentukan karakter melalui sekolah sehat dan ramah anak di SMP Negeri 7 Kota Ternate adalah telah terjalin sikap kerjasama dan bersikap ramah di lingkungan sekolah.
\end{abstract}

Kata Kunci: Pembentukan karakter, peserta didik, sekolah sehat, ramah anak

\section{PENDAHULUAN}

Karakter atau dalam Islam sering disebut dengan akhlak, dalam pandangan Islam adalah suatu kepribadian yang mengandung tiga komponen yaitu; pengetahuan, sikap dan perilaku (Nata, 2013). Seseorang dikatakan berkepribadian utuh apabila terdapat keserasian antara tiga hal tersebut, yakni pengetahuan, sikap dan perilaku. Sebagai contoh misalnya, apa yang orang tahu tentang "jujur" itu baik, maka hal itu dia jadikan sebagai sikap dan prilakunya. Apabila seseorang tahu bahwa jujur itu baik, akan tetapi dia berbuat dusta, maka kepribadian orang tersebut tidak bisa dikatakan kepribadian utuh akan tetapi dikatakan sebagai kepribadian pecah (split personality). Proses pendidikan karakter dipandang sebagai usaha sadar dan terencana, bukan usaha yang sifatnya terjadi secara kebetulan. Atas dasar ini, pendidikan karakter adalah usaha yang sungguh-sungguh untuk memahami, membentuk, memupuk nilai-nilai etika, baik untuk diri sendiri maupun semua warga masyarakat secara keseluruhan (Harun, 2015; Sardiman A.M, 2010).

Setiap anak perlu mendapatkan kesempatan untuk tumbuh dan berkembang secara optimal, baik fisik, mental maupun sosial, karena anak merupakan generasi penerus bangsa yang memiliki hak dan kewajiban ikut serta membangun Negara. Anak merupakan subjek dan objek pembangunan nasional Indonesia dalam usaha mencapai aspirasi Bangsa Indonesia, masyarakat yang adil dan makmur baik secara spiritual maupun materil. Pendidikan dalam keluarga sangatlah penting dan merupakan pilar pokok pembangunan karakter seorang anak. Pendidikan dasar wajib dimiliki tidak hanya oleh masyarakat kota, tetapi juga masyarakat pedesaan (Redja, 2001). Seseorang yang memiliki tingkat pendidikan tinggi cenderung lebih dihormati karena dianggap berada pada strata sosial yang tinggi. Kualitas seseorang dilihat dari bagaimana dia dapat menempatkan dirinya dalam berbagai situasi. Orang 
tua seharusnya memahami bahwa merekalah sebagai penanggung jawab utama dalam pendidikan putraputrinya. Dan secara umum, berhasil tidaknya pendidikan seorang anak biasanya dihubungkan dengan perkembangan pribadi orang tuanya dan baik tidaknya hubungan, komunikasi dan role model dalam keluarga (Hasyim, 2016).

Menurut Undang-Undang No. 23 Tahun 2002 tentang Perlindungan Anak, anak didefinisikan sebagai seseorang yang belum berusia 18 (delapan belas) tahun, termasuk anak yang masih dalam kandungan. Baik anak dan orang dewasa dapat tumbuh dan mengembangkan potensi dirinya secara optimal jauh dari ketakutan akan kekerasan. Maka penting dan perlu adanya pemberdayaan terhadap anak, dengan tujuan agar tiap individu dapat mengembangkan kepribadian, menggali potensi dan menumbuhkan kepercayaan diri yang baik. Mengingat anak merupakan generasi penerus bangsa dimasa yang akan datang, maka sudah selayaknya negara melindungi dan menjaga generasi mudanya dari hal-hal buruk yang kemungkinan akan terjadi. Negara berkewajiban memenuhi 2 hak setiap anak atas kelangsungan hidup, tumbuh dan berkembang, berpartisipasi serta mendapatkan perlindungan dari tindak kekerasan dan diskriminasi. Tidak terpenuhinya hak anak akan menurunkan kualitas hidup anak dan pada akhirnya akan menimbulkan masalah bagi negara, pemerintah, masyarakat, keluarga dan orangtua. Agar positive character terbentuk, maka perlu pembiasaan mandiri, sopan santun, kreatif dan tangkas, rajin bekerja, dan punya tanggung jawab (Harun, 2015).

Kemajuan suatu bangsa tidak terlepas dari bagaimana bangsa itu mendidik anak-anaknya. Pendidikan sebagai pilar pencerdasan dan pembentukan karakter kehidupan bangsa memberikan peranan penting dalam melahirkan sumber daya manusia yang berkualitas dan berdaya saing baik dari aspek jasmaniah maupun aspek rohaniah (Permono \& Psi, 2013). Sekolah adalah lembaga pendidikan yang berfungsi sebagai pendukung utama sistem pendidikan di Indonesia. Dengan dukungan sekolah dan peran serta guru dan siswa sistem pembelajaran dapat berjalan dengan baik. Terlebih lagi jika didukung sarana dan prasarana yang lengkap, tentu dapat memotivasi siswa untuk belajar dengan serius dan bisa meraih prestasi. Tidak dipungkiri bahwa pendidikan di masa ini sudah banyak dipengaruhi budaya global. Pesatnya pengaruh budaya global yang tersebar luas dan mudah sangat cepat dapat mempengaruhi cara pandang, gaya hidup dan budaya suatu bangsa. Arus budaya global dengan cepat membanjiri kita, seolah-olah tidak memberi kesempatan kepada kita untuk menyerap dengan filter mental dan sikap kritis (Hasyim, 2016).

SMP Negeri 7 merupakan salah satu sekolah ramah anak di Ternate yang mendapat kunjungan Menteri Pemberdayaan Perempuan dan Perlindungan Anak. Menteri Pembedayaan Perempuan dan Perlindungan Anak mengatakan bahwa ada beberapa indikator untuk menjadikan sekolah ramah anak, seperti bebas rokok, miras, narkoba, memiliki kantin sehat, serta siswanya tidak pernah membolos. Jangan terpengaruh dengan anak-anak yang suka merokok, minum minuman keras dan narkoba. Karena tugas anak-anak sekarang adalah belajar, sebab masa depan anak-anak ada di tangan anak-anak sendiri. SMP Negeri 7 Kota Ternate dikenal dengan sekolah yang bersih dan juga lingkungan yang ramah, sekolah ini mendapat perhatian dari pemerintah karena memiliki lingkungan sekolah yang dianggap bersih. Menteri juga berpesan kepada semua sekolah ramah anak di Indonesia, khususnya di Kota Ternate, agar terus mempertahankan ini karena pihaknya siap mendampingi. Menurut (Sholeh \& Humaidi, 2016) saat ini, Sekolah Ramah Anak di seluruh Indonesia berjumlah 1.400, yang betul-betul ramah anak, bebas rokok, minuman keras dan narkoba. Sebelumnya, Wakil Walikota Ternate, Abdullah Tahir dalam sambutannya mengatakan, salah satu upaya strategis untuk pemenuhan hak atas pendidikan adalah melalui pengembangan Sekolah Ramah Anak guna memenuhi indikator Ternate menjadi Kota Layak Anak. Di SMP Negeri 7 Kota Ternate yang berlokasi di Kecamatan Ternate Tengah, Kota Ternate, Propinsi Maluku Utara, adalah salah satu sekolah yang mendapat gelar sebagai sekolah sehat dan ramah anak. Berdasarkan hasil pengamatan, maka permasalahan yang diajukan dalam tulisan ini adalah bagaimana pola pembentukan karakter peserta didik melalui program sekolah sehat dan ramah anak di SMP Negeri 7 Kota Ternate? 


\section{METODE PENELITIAN}

Penelitian ini dilaksanakan di SMPN 7 Kota Ternate pada bulan Desember 2018. Metode penelitian yang digunakan adalah jenis penelitian deskriptif kualitatif (Afifuddin \& Saebani, 2009; Sugiyono, 2012). Pengumpulan data menggunakan dua prosedur antara lain; pengumpulan data primer dan data sekunder. Pengumpulan data primer diperoleh melalui teknik observasi, wawancara, dan dokumentasi. Data sekunder yaitu, data yang diperoleh melalui penelusuran dan penelaahan dokumen profil sekolah. Analisis data dilakukan dengan pendekatan deskriptif kualitatif. Menurut Hubermas dalam (Sugiyono, 2012), bahwa aktivitas dalam analisis data kualitatif dilakukan secara interaktif dan berlangsung secara terus menerus sampai tuntas, sehingga datanya dikatakan sudah jenuh. Aktivitas dalam analisis data dengan cara reduksi data, penyajian data, dan verifikasi data. Setelah data diverifikasi, maka langkah selanjutnya adalah data dianalisis menggunakan analisis deskriptif.

\section{HASIL PENELITIAN DAN PEMBAHASAN}

\section{Pola Pembentukan Karakter Peserta Didik Melalui Sekolah Sehat dan Ramah Anak di SMP Negeri 7 Kota Ternate}

Berdasarkan hasil penelitian tentang pola pembentukan karakter peserta didik melalui sekolah Sehat dan ramah anak, kepala sekolah (Hadi Abdullah) menjelaskan bahwa pembentukan karakter peserta didik melalui sekolah sehat dan ramah anak sebenarnya sudah terbentuk dan sudah bisa dilihat dari keseharian peserta didik. Hal ini dapat dibuktikan bahwa di SMP Negeri 7 Kota Ternate yang keseharian disekolah yang selalu bersikap jujur. Sikap jujur sudah kami tanamkan kepada diri peserta didik sehingga mereka selalu bersikap jujur dalam hal apapun, cara yang kami lakukan untuk menanamkan sikap jujur yaitu melalui arahan-arahan yang selalu diberikan, contoh pada apel pagi dan juga pada memulai pelajaran selalu diberikan arahan terlebih dahulu. Pola atau cara yang dilakukan secara terus menerus, karena untuk membentuk karakter peserta didik yang nakal dan lain sebagainya harus ditanamkan sikap baik agar peserta didik terbiasa dengan bersikap jujur.

Pembentukan karakter anak juga sangat dipengaruhi oleh karakter, perilaku bahkan kata-kata yang biasa diucapkan oleh orang tua. Banyak anak yang merasa kurang percaya diri, atau terlalu percaya diri karena kesalahan pola asuh orang tua, Banyak anak yang menjadi kurban pelecehan dari orang tuanya secara fisik, tetapi tanpa disadari banyak dari kita sebagai orang tua melukai anak dengan kata-kata kita, yang juga dapat 'membunuh' anak kita. Kata-kata sederhana seperti 'anak bodoh', anak sial', 'anak malas', 'anak nakal', 'si buruk rupa', 'kamu tidak sepintar kakakmu', dapat meninggalkan luka yang sangat dalam di diri anak-anak, yang nantinya akan sangat berpengaruh dalam perkembangan karakternya (Yusuf \& Hasyim, 2016).

Pembentukan karakter peserta didik melalui sekolah sehat dan ramah anak di SMP Negeri 7 Kota Ternate sudah dilakukan, dengan pola atau cara memberi arahan-arahan pada mapel dan di kelas sebelum memulai pelajaran, atau jika peserta didik ribut maka pelajaran tidak dimulai namun diganti dengan guru memberi nasehat agar peserta didik mulai menyadari kesalahan-kesalahan mereka, guru selalu mengigatkan kepada peserta didik agar tidak melakukan perbuatan yang salah karena mereka ingin peserta didik fokus dengan sekolah dan tugas-tugas yang diberikan. Guru di sekolah tidak hanya jadi pengajar saja namun juga sebagai panutan bagi peserta didik, mulai dari mengajarkan agar tidak melakukan perbuatan yang salah, mereka juga selalu diajarkan agar bisa membedakan perbuatanperbuatan yang boleh dilakukan dan yang tidak boleh dilakukan, misalnya selalu jujur dalam mengejakan tugas sekolah dan juga disiplin dalam hal apapun kalau diberi tanggung jawab, karena dalam bersikap jujur dalam hal apapun dan selalu disiplin merupakan bagian dari program sekolah sehat dan ramah anak.

Pola pembentukan karakter peserta didik melalui sekolah sehat dan ramah anak di SMP Negeri 7 Kota Ternate sudah dilakukan dan sampai saat ini karater peserta didik disekolah masih bisa dikatakan baik 
dalam hal melakukan dan mengerjakan tugas maupun pekerjaan lingkungan (fisik) peserta didik masih bersikap jujur, disiplin dan bekerjasama. Peran guru tidaklah terbatas di dalam masyarakat, bahkan pada hakikatnya merupakan komponen yang strategis yang memilih peran yang penting dalam menentukan gerak maju kehidupan bangsa. Bahkan keberadaan guru merupakan faktor condisio since quanon yang tidak mungkin digantikan oleh komponen mana pun dalam kehidupan bangsa sejak dulu, terlebih-lebih pada era kontemporer ini. Keberadaan guru sebagai suatu bangsa amatlah penting, apalagi bagi suatu bangsa yang sedang membangun, terlebih-lebih bagi keberlangsungan hidup bangsa di tengah-tengah lintasan perjalanan zaman dengan teknologi yang kian cangih dan segala perubahan serta pergeseran nilai yang cenderung memberi nuansa kepada kehidupan yang menuntut ilmu dan seni dalam kadar dinamika untuk dapat mengadaptasikan. Semakin akurat para guru melaksanakan fungsinya, semakin terjamin tercipta dan terbinanya kesiapan dan keandalan seseorang sebagai manusia pembangunan. Dengan kata lain, potret dan wajah diri bangsa dimasa depan tercermin dari potret diri para guru masa kini, dan gerak maju dinamika kehidupan bangsa berbanding lurus dengan citra para guru di tengahtengah masyarakat (Hasyim, 2016).

Pembentukan karakter peserta didik melalui sekolah sehat dan ramah anak sudah berjalan dengan baik karena guru-guru di sekolah sudah membentuk karakter peserta didik yang tadinya malas belajar dan mengerjakan tugas, kurang disiplin dalam mengerjakan tugas menjadi lebih giat lagi dalam mengerjakan tugas-tugas sekolah (Harun, 2015). Dan dalam mengerjakan tugas sekolah teman-teman selalu bersikap jujur dan disiplin, karena dalam mengerjakan tugas sekolah bersikap jujur merupakan perbuatan yang baik dan dilakukan oleh diri kita sendiri. Saat mengerjakan tugas dengan jujur peserta didik merasa senang karena akan mendapat penilaian dari guru mata pelajaran bahwa peserta didik tersebut bersikap jujur dalam mengerjakan tugas.

Penulis mengidentifikasikan hasil penelitian, dokumentasi, dan teori-teori yang relevan maka dapat dianalisis bahwa pola pembentukan karakter peserta didik melalui sekolah sehat dan ramah anak di SMP Negeri 7 Kota Ternate sudah diterapkan dan berjalan dengan baik. Hal ini dapat dilihat bahwa keseharian peserta didik di sekolah selalu bersikap baik dan saling menghargai, serta menghormati orang lain. Karakter peserta didik di sekolah terbentuk mulai dari selalu mencium tangan para guru apabila masuk ke kelas dan bertemu di luar kelas. Bukan hanya para guru saja peserta didik bersikap demikian tetapi kepada stiap orang tua yang datang berkunjung kesekolah tersebut. Dan hal tersebut dirasakan sendiri oleh peneliti ketika penelitian di sekolah tersebut.

Dari uraian diatas dapat disimpuljan bahwa, guru merupakan faktor yang sangat dominan dan paling penting dalam pendidikan formal pada umumnya karena bagi peserta didik, guru sering dijadikan tokoh teladan, bahkan menjadi tokoh identifikasi diri. Oleh sebab itu, guru seyogyanya memiliki perilaku dan kemampuan yang memadai untuk mengembangkan siswanya secara utuh. Kenyataan di lapangan menunjukan bahwa unjuk kerja (performance) guru didalam melaksanakan kegiatan belajar mengajar (KBM) sangat bervariasi dan kualifikasi keguruannya beraneka ragam. Disisi lain banyak terdapat guru yang mengasuh dan mempertanggung jawabkan mata pelajaran yang tidak sesuai dengan wewenang dan kemampuan profesionalnya serta kemajuan dan perkembangan ilmu pengetahuan dan teknologi yang telah menuntut adanya penyesuaian dan perkembangan professional guru untuk dapat mengembangkan pendidikan di sekolah, khususnya dalam ahli teknologi. Berdasarkan hal-hal di atas maka perlu ditingkatkan kemampuan profesional para pengawas, kepala sekolah, guru dan tenaga pendidik lainnya, dalam upaya mengelola pembelajaran para siswa secara baik/benar dan berhasil guna (Hayun \& Hasyim, 2018).

\section{Faktor-faktor yang Mempengaruhi Pembentukan Karakter melalui Sekolah Sehat dan Ramah Anak di SMP Negeri 7 Kota Ternate}

Pembentukan karakter peserta didik selalu dipengaruhi dengan faktor-faktor yang ada pada diri peserta keturunan, lingkungan, dan kejiwaan (Suyanto, 2012). Faktor biologis peserta didik ini biasanya pengaruh dari kedua orang tuanya yang misalkan salah satu dari mereka memiliki karakter kurang baik maka akan berdampak pada anaknya, dan faktor lingkungan bisa jadi kalau dilingkungan keluarga dan 
masyarakat baik maka peserta didik tersebut akan baik juga dan sebaliknya kalau lingkungan buruk maka akan berpengaruh pada karakter peserta didik, dan faktor kejiwaan yang berasal dari dalam diri peserta didik itu sendiri yang bepengaruh terhadap pembentukan karakter.

Khususnya dalam masyarakat yang jauh dari jangkauan lembaga hukum atau dimana hukum formal Negara kurang kuat pengaruhnya ketimbang norma-norma masyarakat yang lain, definisi kenakalan menurut atas pelanggaran hukum ini memang bisa menimbulkan kesulitan. Dengan adanya UndangUndang Wajib Belajar untuk anak-anak di atas umur 7 tahun dan tidak bersokolah dapat dinyatakan nakal karena melanggar Undang-Undang. Tetapi dibanyak bagian negara ini banyak sekali anak yang tidak sekolah karena kondisinya memang tidak rnemungkinkan atau masyarakatnya memang tidak mementingkan sekolah untuk anak-anaknya. Atau dalam hal lain mungkin seorang anak dapat dianggap nakal karena melanggar Undang-Undang tentang lingkungan hidup karena mereka membantu orang tua mereka menggali pasir sungai yang menyebabkan erosi. Dalam hal-hal seperti ini, untuk menilai atau mendiagnosa kenakalan anak atau remaja hendaknya diperhatikan faktor kesengajaan dan kesadaran dari anak. Selama anak atau remaja itu tidak tahu, tidak sadar dan tidak sengaja melanggar hukum dan tidak tahu pula akan konsekuensinya, maka ia tidak dapat digolongkan sebagai anak nakal.

Oleh karena itu, pembangunan karakter tidak dapat terlepas dari keluarga, sekolah dan lingkungan sekitar individu tersebut. Keluarga merupakan hal yang terpenting, karena keluarga ibarat akar yang menentukan akan menjadi apa dan bagaimana seorang individu tersebut. Bila keluarga menjalankan fungsinya dengan baik, maka individu-individu yang dilahirkan akan mempunyai moral dan karakter yang baik sehingga dapat membentuk sumber daya manusia yang berkualitas. Bukan tidak mungkin bila negara kita dapat terlepas dari berbagai masalah krisis moral karena disusun oleh masyarakat yang mempunyai keluarga yang berfungsi dengan baik (Hasyim, 2016).

Sejalan dengan itu, program pembinaan sumberdaya manusia pendidik oleh Dinas Pendidikan Kota Ternate meliputi; program Diklat para guru pada setiap jenjang pendidikan (SD, SMP dan SMA). Peningkatan proses pendidikan dilakukan melalui pembinaan kepribadian, sikap, dan kemampuan teknis profesionalisme guru dilakukan melalui penataran dan pemanfaatan wadah Kelompok Kerja Guru, Kelompok Guru Mata Pelajaran, Kelompok Kerja Kepala Sekolah, Dan Kelompok Kerja Pengawas Sekolah. Pembinaan mutu guru juga dilakukan program penyetaraan Guru Sekolah Dasar (PGSD). Bertujuan meningkatkan mutu lulusan Sekolah Dasar melalui peningkatan pendidikan guru minimal pada jenjang Diploma Dua (D-II). Pembinaan mutu guru juga dilakukan melalui promosi jabatan guru. Promosi jabatan meliputi jabatan inti, guru pemandu bidang studi, kepala sekolah maupun pengawas sekolah. Promosi juga memperhatikan sikap dan kepribadian dalam melaksanakan tugas yang meliputi kegiatan guru dimasyarakat, organisasi sosial dan keagamaan, kepramukaan, maupun kepengurusan dalam PGRI. Program pembinaan guru dilakukan melalui penataran-penataran yang berkaitan dengan seluruh bidang studi diajarkan di sekolah (Hayun \& Hasyim, 2018; Rajaloa \& Hasim, 2018; Yusuf \& Hasyim, 2016).

Proses pembentukan karakter peserta didik ada beberapa faktor yang berpengaruh misalkan faktor biologi yaitu bawaan sejak lahir dan faktor lingkungan tempat keluarga dan masyarakat peserta didik, yang dimana sangat berpengaruh dalam proses pembentukan karakter. Pengaruh lingkungan tersebut misalkan memiliki sifat malas belajar yang dipengaruhi oleh lingkungan akan terbawa-bawa ke lingkungan sekolah yang tidak suka belajar, ada beberapa peserta didik disekolah yang lebih suka olahraga dari pada belajar di kelas. Faktor biologis adalah mewarisi salah satu sifat orang tua kita sendiri atau disebut faktor keturunan, saya lebih mengikuti ayah yang suka marah-mara dan banyak bicara. Faktor lingkungan yaitu tempat dimana kita tinggal dan lingkungan saya berpengaruh terhadap diri saya karena malas dirumah lebih sering keluar rumah dan bermain dengan teman-teman diluar. Faktor kejiwaan ialah yang ada pada diri kita sendiri misalnya malas rapih kesekolah.

Penulis mengidentifikasikan hasil penelitian, dokumentasi, dan teori-teori yang relevan maka dapat dianalisis bahwa pembentukan karakter peserta didik dipengaruhi oleh beberapa faktor yang menjadi 
pengaruh dilihat dari faktor biologis, lingkungan dan kejiwaan peserta didik. Meskipun demikian karakter peserta didik di SMP Negeri 7 Kota Ternate masih tergolong baik karena dilihat dari sikap peserta didik yang aktif dan berlaku dalam lingkungan sekolah. Lingkungan sekolah yang tergolong baik dan ramah terhadap setiap orang menunjukkan sekolah tersebut akan memiliki peserta didik yang berkualitas dalam hal karakter. Lingkungan tempat kita tinggal dan mendiami di tempat tersebut akan berpengaruh namun ada juga hal-hal positif yang dapat kita ambil dan mengikutinya.

Menyadari betapa pentingnya peningkatan kualitas pendidikan, pemerintah Kota Ternate telah melakukan berbagai upaya. Termasuk diantaranya mengeluarkan surat keputusan walikota dalam rangka menata sistem perencanaan tentang rincian tugas pada Dinas Pendidikan Nasional Kota Ternate meliputi; susunan organisasi, kepala dinas, bagian tata usaha, bagian umum, bagian kepegawaian, bagian perencanaan dan evaluasi, sub dinas pendidikan dasar dan taman kanak-kanak, sub dinas menegah, umum, dan kejuruan, cabang-cabang dinas dan unit pelaksanaan teknis diknas. Sehingga diharapkan program-program pendidikan yang dihasilkan oleh sistem perencanaan tersebut berhasil membawa masyarakat meraih tujuan pendidikan yang dicita-citakan. Kantor dinas pendidikan Kota Ternate merupakan salah satu organisasi/lembaga yang berkedudukan sebagai unsur pelaksana pemerintah daerah yang bertugas melaksanakan kewenangan otonomi daerah di bidang pendidikan dalam rangka tugas desentralisasi. Sebagai pelaksana, dinas pendidikan memiliki fungsi yang sangat strategis dalam mengelola penyelengaraan sistem pendidikan. Sehubungan dengan hal tersebut, kantor dinas pendidikan Kota Ternate dituntut untuk melasanakan manajemen sumberdaya manusia yang baik, sehingga dapat lebih meningkatkan kualitas dalam memberikan pelayanan kepada publik, terutama yang berhubungan dengan di pendidikan di Kota Ternate.Untuk mewujudkan kinerja dinas pendidikan Kota Ternate yang baik dipengaruhi oleh banyak faktor, salah satunya adalah manajemen sumberdaya manusia (Rajaloa \& Hasim, 2018).

\section{KESIMPULAN}

Dari hasil penelitian dan pembahasan tersebut dapat disimpulkan sebagai berikut:

1. Pola pembentukan karakter peserta didik melalui program sekolah sehat dan ramah anak di SMP Negeri 7 Kota Ternate sudah berjalan dengan cukup baik. Pola atau cara yang dilakukan untuk memebentuk karakter peserta didik adalah dengan melakukan atau mengingatkan mereka setiap hari tentang hal-hal yang baik dan benar. Hal ini dapat dibuktikan dengan keseharian peserta didik di lingkungan sekolah yang selalu bersikap baik, saling menghargai dan menghormati orang lain di lingkungan sekolah. Bahkan bukan hanya orang-orang di lingkungan sekolah saja, namun juga pada orang-orang yang datang dan berkunjung ke sekolah tersebut.

2. Adapun faktor-faktor yang mempengaruhi pembentukan karakter di SMP Negeri 7 Kota Ternate yang terdapat pada setiap diri peserta didik namun pembentukan karakter peserta didik di sekolah tersebut dapat dibentuk dengan cukup baik. Karena walaupun ada beberapa faktor yang mempengaruhi seperti faktor, biologis, lingkungan, dan kejiwaan, tetapi tidak menjadi sebuah persoalan untuk proses pembentukan karakter peserta didik di sekolah tersebut. Guru-guru di sekolah tersebut punya cara tersendiri untuk mengajak peserta didik dalam melakukan hal-hal yang benar.

3. Pembentukan karakter peserta didik di SMP Negeri 7 Kota Ternate haruslah dijaga dan dikembangkan agar peserta didik lebih giat dan lebih baik dalam melakukan perbuatan-perbuatan baik. Agar hidup saling menghargai dan menghormati tetap terjalin dengan baik di SMP Negeri 7 Kota Ternate. Hal ini merupakan sesuatu yang perlu dikembangkan agar menciptakan peserta didik yang berkualitas. Pembentukan karakter peserta didik di SMP Negeri 7 Kota Ternate yang dilakukan oleh guru-guru tersebut harus dikembangkan dan dijaga agar terus diterapkan dalam sekolah.

\section{DAFTAR PUSTAKA}

Afifuddin, B. A. S., \& Saebani, B. A. (2009). Metodologi Penelitian Kualitatif. In Bandung: CV Pustaka Setia. Harun, C. Z. (2015). Manajemen pendidikan karakter. Jurnal Pendidikan Karakter. 
https://doi.org/10.1017/CBO9781107415324.004

Hasyim, R. (2016). PERANAN ORANG TUA DALAM PEMBENTUKAN MORAL SISWA DI SD NEGERI TABAM KECAMATAN KOTA TERNATE UTARA. PEDAGOGIK, 4(1).

Hayun, S., \& Hasyim, R. (2018). MANAJEMEN KOMPETENSI GURU NEGERI OLEH DINAS PENDIDIKAN KABUPATEN HALMAHERA TIMUR. GeoCivic, 1(1), 14-25.

Nata, A. (2013). Akhlak Tasawuf dan Karakter Mulia. In Jakarta: Raja Grafindo Persada.

Permono, H., \& Psi, M. (2013). Peran Orang Tua dalam Optimalisasi Tumbuh Kembang Anak untuk Membangun Karakter Anak Usia Dini. Prosiding Seminar Nasional Parenting. https://doi.org/10.1111/pce.12022

Rajaloa, N. I., \& Hasim, R. (2018). Manajemen Perencanaan dan Rekrutmen Tenaga Pendidik Oleh Dinas Pendidikan Kota Ternate. EDUKASI, 16(1), 11-28.

Redja, M. (2001). Pengantar Pendidikan. In Jakarta: Rajawali Pers.

Sardiman A.M. (2010). Revitalisasi Peran Pembelajaran IPS Dalam Pembentukan Karakter Bangsa. Jurnal Cakrawala Pendidikan, 29(3), 147-160. https://doi.org/https://doi.org/10.21831/cp.v1i3.242

Sholeh, A. N., \& Humaidi, L. (2016). Panduan Sekolah dan Madrasah Ramah Anak. Jakarta: Erlangga.

Sugiyono. (2012). Metode Penelitian Kuantitatif, Kualitatif Dan R\&D. Bandung: Alfabeta, p. 361. https://doi.org/10.1017/CBO9781107415324.004

Suyanto, S. (2012). Pendidikan Karakter untuk Anak Usia Dini. Pendidikan Karakter Untuk Anak Usia Dini.

Yusuf, M., \& Hasyim, R. (2016). Peranan Guru dalam Membangun Kesadaran Cinta Tanah Air Pada Siswa Sekolah Dasar (Telaah Teoritik). Pedagogik, 4(1), 8-16. 